\title{
SUSTAINABILITY OF AUSTRIAN PUBLIC DEBT: A POLITICAL ECONOMY PERSPECTIVE
}

\author{
GOTTFRIED HABER \\ REINHARD NECK
}

\author{
CESIFO WORKING PAPER NO. 1816 \\ CATEgORY 2: Public CHOICE \\ OCTOBER 2006
}

An electronic version of the paper may be downloaded

- from the SSRN website:

- from the RePEc website:

- from the CESifo website:

www.SSRN.com

www.RePEc.org

www.CESifo-group.de 


\title{
SustainABiLity of Austrian Public DeBt: A POLITICAL ECONOMY PERSPECTIVE
}

\begin{abstract}
Sustainablity of Austrian public debt is investigated in the context of political objectives such as stabilizing the business cycle, increasing chances for being re-elected and implementing the ideologies of political parties. Several tests indicate that Austrian fiscal policies were sustainable in the period 1960-1974, while from 1975 on, public debt grew much more rapidly. The development of public debt in Austria seems to be driven not primarily by ideology, but by structural causes and a shift in the budgetary policy paradigm. We find some empirical evidence that governments in Austria dominated by one party run higher deficits than coalition governments. There are no indications of a political business cycle.
\end{abstract}

JEL Code: H6, E6.

Keywords: fiscal policy, sustainability, time series, political economy.

Gottfried Haber Department of Economics University of Klagenfurt

Universitaetsstr. $65-67$

9020 Klagenfurt

Austria

gottfried.haber@uni-klu.ac.at
Reinhard Neck

Department of Economics

University of Klagenfurt

Universitaetsstr. $65-67$

9020 Klagenfurt

Austria

reinhard.neck@uni-klu.ac.at

The research presented here was supported by the Ludwig Boltzmann Institute for Economic Analyses (Vienna) and the Jubiläumsfonds of the Oesterreichische Nationalbank. 


\section{Introduction}

During the last twenty years, rising public debt has become a key issue in economic policy debates in many European countries, including Austria. The Stability and Growth Pact (SGP) and the Maastricht fiscal criteria for entry into the European Economic and Monetary Union (EMU) aimed at securing sustainable fiscal policies. More recently, however, it has turned out that the rules of the SGP could not be enforced, and that fiscal deficits have surpassed the 3 percent of GDP limit in several EMU countries. Amendments to the SGP rules are being widely discussed, and many observers question policy makers' determination to stick to sustainable fiscal policies.

Apart from the political debate about the SGP, the questions as to which fiscal policy is sustainable in the long run and whether policy makers are ready to succumb to sustainable fiscal policies are of interest. There is wide-spread agreement among economists about sustainability of public finances meaning that budgetary policy observes the long-term government budget constraint. According to this prescription, the sum of discounted future government budgetary surpluses must not be smaller than discounted future government debt including the initial stock of debt. The actual behavior of fiscal policy makers, on the other hand, is much less clear. In particular, to judge whether fiscal policies in a particular country were sustainable over a certain period of time, much information about past, present and future government budgetary policies is required, and assumptions about several parameters are necessary for most tests of this question.

Fortunately, Bohn (1998) has developed a comparatively easy test for sustainability of fiscal policy. His model starts from the reactions of fiscal policy makers to high or rising public debt. A sufficient condition for sustainable fiscal policy demands that policy makers increase the primary surplus as a reaction to increased public debt in the previous period, and that this reaction is sufficiently strong. Here we combine such an analysis for Austria with an 
investigation of political influences on fiscal policies and an attempt at a preliminary evaluation of Austria's public debt development.

This paper is structured as follows: Section II briefly applies Bohn's sustainability test to Austrian data. In Section III, some political determinants of Austrian budgetary policies are investigated as we test for the influence of unemployment, the ideologies of political parties, and political cycles. Finally, Section IV summarizes the results of the paper and discusses future prospects for fiscal policy in Austria. For more details on sustainability tests for Austria, see Neck and Haber (2006), for an earlier analysis along similar lines, Neck and Getzner (2001).

\section{Bohn's Sustainability Model}

For the context of the US, Bohn $(1998,2006)$ developed a model to test whether fiscal policy is sustainable. This model can also be used as a starting point for a positive explanation of actual budgetary policy making. In his model, the following equation is estimated:

$$
p s_{t}=\rho d_{t-1}+\alpha_{0}+A Z_{t}+\varepsilon_{t}
$$

where $p s_{t}$ denotes the primary surplus of period $t, d_{t}$ is the stock of central government debt in period $t$, and $Z_{t}$ is a vector of additional influential variables like deviations of GDP or public expenditures from their trend. The latter emerge as explanatory variables for the budgetary stance from the tax-smoothing theory of Barro (1979), but they did not become significant for Austrian data. All variables in (1) are measured as their respective ratios to GDP. Fiscal policy can be shown to be sustainable if in equation (1) $\rho$ is positive and sufficiently large, meaning that fiscal policy makers react to a high stock of debt at the beginning of period $t$ by increasing the primary surplus (or reducing the primary deficit) in period $t$. 
Table 1: Bohn's Sustainability Model for Austria (dependent variable: primary surplus of the federal government budget, ratio to GDP)

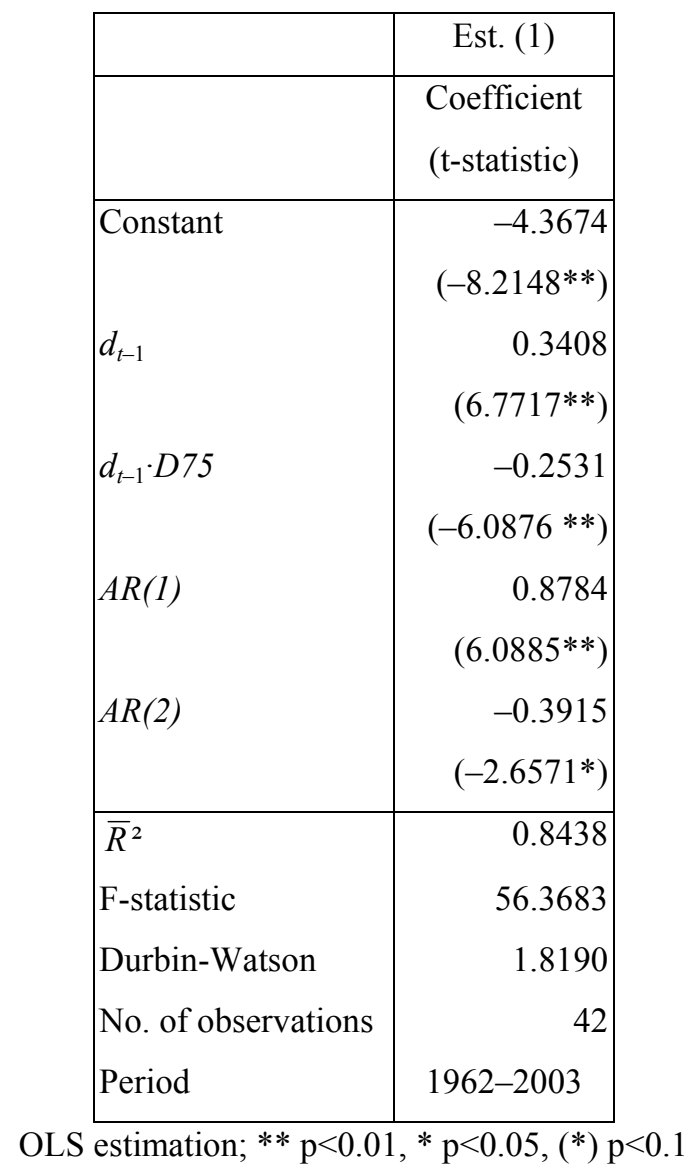

Testing for a unit root of the primary surplus-to-GDP ratio by the augmented Dickey-Fuller and the Phillips-Perron test results in rejecting the hypothesis of a unit root at the $5 \%$ (ADF test) and $10 \%$ (PP test) significance levels, hence we assume stationarity of the dependent variable. Table 1 shows an estimation of equation (1). Inspection of Austrian data and several tests clearly show that there is a structural break in $1974 / 1975$, when the effects of the first oil price shock hit the Austrian economy. Hence we introduce a dummy variable $D 75$ (D75 = 1 for the period 1975-2003). Multiplying this dummy variable for the period after 1974 by the coefficient for the debt-to-GDP ratio $d_{t}$ instead of the constant adds explanatory power to the model. To remove serial correlation of the residuals, two autoregressive terms have to be included. In the resulting estimted equation (Est. (1)), the sign and size of the coefficients indicate that the process of the development of primary surplus has a clear mean-reverting 
tendency in the first period (1960-1974); that tendency still exists but is much weaker in the second period (1975-2003).

\section{Austrian Fiscal Sustainability from a Public Choice Point of View}

Obviously, Austrian federal public debt has grown considerably since World War II, especially since 1975 . To answer the question as to the reasons for this development, one may start with the fiscal policy concept of "Austrokeynesianism", which has prevailed in Austria for some time. From the 1970s on, "full employment" (keeping down and reducing unemployment) was the central target of Austrian policy makers. The main instrument intended to reach this goal was expansionary fiscal policy - although the concept of "Austrokeynesianism" always included other elements, such as the "hard-currency" monetary policy, pegging the Austrian currency strictly to the Deutschmark, and the "economic and social partnership", an agreed-upon policy of moderate wage and price increases negotiated by the employers' and employees' associations. Unemployment rose during most of the period after 1974, so this policy may have contributed to increasing budget deficits and, consequently, public debt.

The ideologies of the political parties forming the central (federal) government can serve as another explanation for the growth of public debt. Left-wing parties are said to be more ready to accept budget deficits because they tend to engage in Keynesian stabilization policies with the aim of smoothing the business cycle and lowering unemployment. Price stability or balanced budgets are not that important for these parties. Right-wing parties follow the opposite path. They are more concerned about financial goals like small deficits or price stability than about unemployment or stabilizing the business cycle. 
Another public-choice explanation of public debt growth is based on the different forms of government. If a coalition government of two or more parties rules a country, some publicchoice theories hypothesize that these parties engage in a "war of attrition". Each party tries to fulfill obligations to its own voters (cf. Roubini and Sachs, 1989). As all parties are in the same situation, they expand government expenditures to please their voters and to avoid mutual conflicts with their partners in government. The result is increasing public debt.

In contrast to the distributional conflicts sketched above, we can also think of the opposite effect. Coalition governments might find it easier to stabilize their budget because they have a larger majority in parliament. In a situation where only one party is in charge, a strong opposition might make voters think that the ruling party is solely responsible for the painful policies of budget consolidation. Ruling parties might, therefore, be reluctant to consolidate the budget. Coalition governments without such a strong opposition might have more courage and power to introduce the unpopular measures required to consolidate public finances.

Fiscal illusion is another explanation for governments running budget deficits. It is hypothesized that voters systematically overestimate the benefits of present deficit-financed government expenditures (e.g. transfers) while underestimating the corresponding future tax burden. This means that they do not understand the intertemporal budget constraint of the government. Politicians react to such fiscal illusions in an opportunistic way. Particularly before elections, they increase government expenditures in order to be re-elected by "fiscally illuded" voters. This theory has dramatic consequences for Keynesian stabilization policies: Politicians are willing to increase deficits during recessions, but are not willing to increase the primary surplus sufficiently when the recession is over.

The theory of fiscal illusion is related to the literature on political business cycles in the sense that there is an incentive for politicians to promise or actually realize an increase in transfers 
or a decrease in taxes before elections. An additional consideration entering fiscal policy making might be the time left until the next elections, because voters can be assumed to be myopic. Painful budget consolidation policies may be more likely immediately after elections than in the period shortly before the next elections. A major problem with fiscal illusion and political business cycle theories is that they may explain short-term fluctuations in output and government debt but are not able to explain different development patterns between countries and the long-term growth of government debt in several European countries (Alesina and Perotti, 1995).

\subsection{Unemployment and Fiscal Policies}

Table 2 presents an estimation of Bohn's sustainability model of fiscal policy with the rate of unemployment $U R$ included as an explanatory variable (as the only element of the vector $Z_{t}$ ). The estimator for the influence of the unemployment rate $U R$ is significantly negative, corresponding to our expectations (Est. (2)). The results of this estimation again suggest a significant reaction of the primary surplus to the debt-to-GDP ratio of the previous year and, in addition, to the rate of unemployment. An increase in the unemployment rate by one percentage point would ceteris paribus lead to a reduction in the primary surplus-to-GDP ratio of more than 0.7 percentage points. Such a reaction can be explained by automatic stabilizers and by discretionary counter-cyclical policies ("deficit spending"). The reaction of fiscal policy makers to increasing unemployment further weakens the sustainability orientation beyond the already lower reactions of policy makers to increased public debt in the second period (1975-2003). 
Table 2: Influence of the Unemployment Rate on Budgetary Policies in Austria (dependent variable: primary surplus of the federal government budget, ratio to GDP)

\begin{tabular}{|c|c|c|c|}
\hline & Est. (2) & Est. (3) & Est. (4) \\
\hline & $\begin{array}{l}\text { Coefficient } \\
\text { (t-statistic) }\end{array}$ & $\begin{array}{l}\text { Coefficient } \\
\text { (t-statistic) }\end{array}$ & $\begin{array}{l}\text { Coefficient } \\
\text { (t-statistic) }\end{array}$ \\
\hline \multirow[t]{2}{*}{ Constant } & -4.0096 & -3.9997 & -4.2874 \\
\hline & $\left(-10.2096^{* *}\right)$ & $(-14.4106 * *)$ & $(-10.0228 * *)$ \\
\hline \multirow[t]{2}{*}{$d_{t-1}$} & 0.4472 & 0.3178 & 0.335800 \\
\hline & $(10.0417 * *)$ & $\left(11.5918^{* *}\right)$ & $(8.0280 * *)$ \\
\hline \multirow[t]{2}{*}{$d_{t-1} \cdot D 75$} & -0.2825 & -0.1147 & -0.249569 \\
\hline & $(-8.9082 * *)$ & $(-3.4194 * *)$ & $(-7.2122 * *)$ \\
\hline \multirow[t]{2}{*}{$U R$} & -0.7190 & & \\
\hline & $\left(-3.9841^{* *}\right)$ & & \\
\hline \multirow[t]{2}{*}{$U R \cdot D 75$} & & -1.0481 & \\
\hline & & $(-5.9731 * *)$ & \\
\hline \multirow[t]{2}{*}{$U R-U R(H P)$} & & & -0.977696 \\
\hline & & & $(-3.4360 * *)$ \\
\hline \multirow[t]{2}{*}{$A R(1)$} & 0.7153 & 0.5794 & 0.748542 \\
\hline & $(4.7327 * *)$ & $(4.2237 * *)$ & $(4.7624 * *)$ \\
\hline \multirow[t]{2}{*}{$A R(2)$} & -0.3903 & -0.5213 & -0.341223 \\
\hline & $(-2.4802 *)$ & $(-3.7610 * *)$ & $(-2.0985 * *)$ \\
\hline $\bar{R}^{2}$ & 0.8831 & 0.8949 & 0.8767 \\
\hline F-statistic & 62.9354 & 70.8459 & 59.3039 \\
\hline Durbin-Watson & 1.9130 & 1.9214 & 1.8115 \\
\hline No. of observations & 42 & 42 & 42 \\
\hline
\end{tabular}

Further tests show that the reactions of fiscal policy makers to rising unemployment are different in the two sub-periods. Estimating the model separately for the periods before and after 1974/1975 leads to an insignificant coefficient for the unemployment rate in the first period (1960-1974) while the coefficient is significantly negative for the second period. Est. (3) presents such evidence on the reactions of fiscal policy to the rate of unemployment after 1974. Austrian decision makers apparently react strongly to rising unemployment rates by driving down the primary surplus to an extent that more than compensates for increases in the primary surplus as a reaction to higher debt-to-GDP ratios. If the unemployment rate 
increased by one percentage point during the years 1975 to 2003, the primary surplus-to-GDP ratio was reduced by more than one percentage point.

Another hypothesis sometimes proposed in the public-choice literature states that governments tend to smoothen the rate of unemployment and react only to deviations of the actual rate from a natural or trend rate of unemployment. The latter can be made operational by applying an HP filter. Trying several alternative specifications with the HP filter did not yield significantly better results than the pervious specifications. For the influence of the deviation of the actual from the trend rate of unemployment, see Est. (4).

As a conclusion, the estimations still show a mean-reverting process for the whole period, which is significantly reduced in the period 1975-2003. This means that the primary surplus (measured as a ratio to GDP) reacted to changes in the central government's debt-to-GDP ratio. However, after the first oil price shock, this reaction was significantly lower than before. Instead, the rate of unemployment played a more important role in the sense of a counter-cyclical (Keynesian) orientation of Austrian fiscal policy.

\subsection{Influence of the GDP Growth Rate}

Instead of the rate of unemployment, cyclical influences may also be reflected in the rate of growth of real GDP. In this case, a low (high) growth rate of real GDP will result in a lower (higher) primary fiscal surplus or a higher (lower) primary fiscal deficit to counteract the growth performance of the economy under consideration. Moreover, high GDP growth might facilitate consolidating public finances, which acts in the same direction as the countercyclical policy hypothesis. Therefore we augment the previous specifications by including the GDP growth rate. Est. (5) in Table 3 gives the best result among the specifications including GDP growth. The respective coefficient is clearly insignificant. We 
conclude that higher GDP growth in Austria does not necessarily lead to lower or higher primary deficits.

Table 3: Effect of the growth rate of real GDP on budgetary policies in Austria (dependent variable: primary surplus of the federal government budget, ratio to GDP)

\begin{tabular}{|c|c|}
\hline & Est. (5) \\
\hline & $\begin{array}{l}\text { Coefficient } \\
\text { (t-statistic) }\end{array}$ \\
\hline Constant & $\begin{array}{r}-3.9450 \\
(-9.9459 * *)\end{array}$ \\
\hline$d_{t-1}$ & $\begin{array}{r}0.4698 \\
(9.5092 * *)\end{array}$ \\
\hline$d_{t-1} \cdot D 75$ & $\begin{array}{r}-0.2980 \\
\left(-8.4875^{* *}\right)\end{array}$ \\
\hline$U R$ & $\begin{array}{r}-0.7734 \\
(-4.1454 * *)\end{array}$ \\
\hline GDP growth & $\begin{array}{r}-4.0434 \\
(-0.9055)\end{array}$ \\
\hline$A R(1)$ & $\begin{array}{r}0.6885 \\
(4.4471 * *)\end{array}$ \\
\hline$A R(2)$ & $\begin{array}{r}-0.3736 \\
(-2.3060 *)\end{array}$ \\
\hline $\bar{R}^{2}$ & 0.8824 \\
\hline F-statistic & 52.2964 \\
\hline Durbin-Watson & 1.9780 \\
\hline No. of observations & 42 \\
\hline Period & $1962-2003$ \\
\hline
\end{tabular}

\subsection{Influence of an Interest Rate Shock}

Interest payments influence public debt directly, and the rate of interest influences public finances through several channels, hence it is straightforward to test for an influence of interest rates on the primary surplus. Several alternative specifications are possible, including the level of the rate of interest, differences in the interest rate, or deviations of the interest rate from some long-run average (an interest rate shock). 
In no specifications tested did the interest rate variable become significant for Austria for the period 1962 to 2003 or a sub-period. Interest rates tried were the secondary market yield of central government bonds and money market rates (EONIA and EURIBOR interest rates and their respective "predecessors" before the EMU).

\subsection{Influence of Political Ideology}

Next, we tested whether ideology played an important role in explaining fiscal policy. We hypothesize that left-wing parties, when playing a crucial role in government, place more emphasis on reducing unemployment and on stabilization policies in general. Such policies could lead to lower rates of unemployment but at the same time increase the budget deficit and lower the primary surplus. Furthermore, left-wing parties may try to influence income distribution and may care less about allocative efficiency. In contrast, right-wing parties may be said to accept higher unemployment rates but to care more about the stability of the federal budget. In the Austrian political system, the Social Democrats (SPÖ) broadly fall under the category of "left-wing" parties while the conservative (Christian Democratic) Austrian People's Party (ÖVP) may be characterized as "right wing" in the above sense.

Given this characterization, it could be argued that the structural break in the time series might be attributable to the change of government from an ÖVP dominated one to an SPÖ dominated government in 1970. However, a series of breakpoint tests clearly indicates that the crucial breaking point occurred in 1975 and not before.

Next, we included a dummy variable $S P$ for the periods from 1960 to 1966 and from 1971 to 1999. $S P$ denotes the participation of the Social Democrats in government. From 1960 to 1966 and from 1983 to 1999, the Social Democrats governed in coalitions with other parties, while during the years 1971 to 1982, they had sole governmental responsibility in Austria. 
We hypothesized that the Social Democrats were more likely to reduce the primary surplus and used the specification that adds the rate of unemployment $U R$ as an explanatory variable. Est. (6) in Table 4 shows no significant influence of social-democratic participation in government on the primary surplus. In accordance with our expectations, the coefficient has a negative sign, but it is completely insignificant.

Table 4: Influence of the Ideology of Political Parties on Budgetary Policies in Austria (dependent variable: primary surplus of the federal government budget, ratio to GDP)

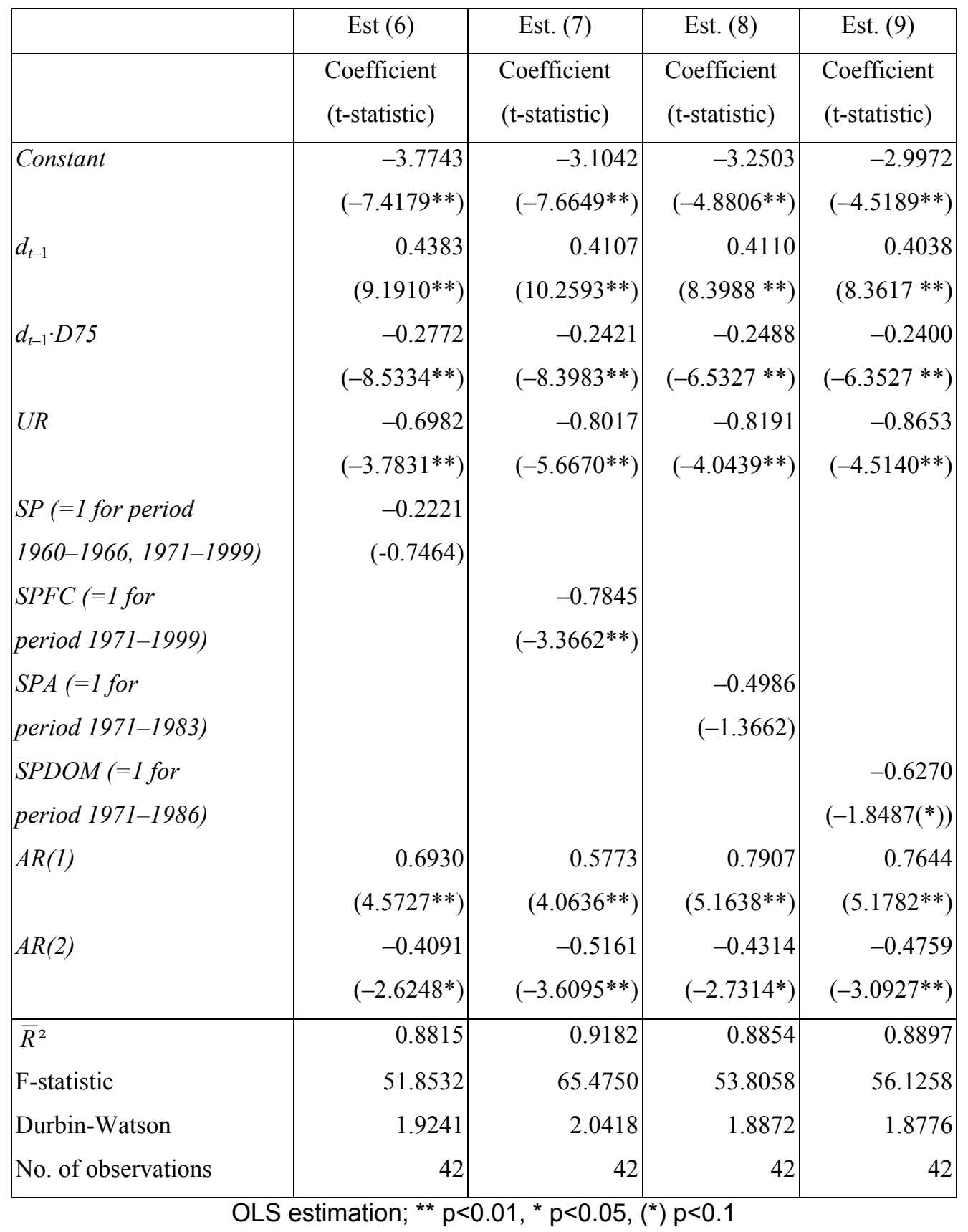


The dummy variable SPFC denotes the period from 1971 to 1999 when the Austrian prime minister (federal chancellor) and the federal minister of finance were Social Democrats. Est. (7) shows that the sign of the coefficient is negative and significant at the 1 percent level. This indicates some deficit-increasing influence of the Social Democrats being in power on the conduct of fiscal policies.

If we look at the years in which the Social Democrats formed one-party governments (the period from 1971 to 1983 , encoded by the dummy variable $S P A$ ), the sign of the coefficient is again negative but not significant at a reasonable level of significance (Est. (8)).

If we consider the period from 1971 to 1986, when the Social Democrats dominated the government - in the period of 1971 to 1983 plus the "Small Coalition" of Social Democrats and the (then predominantly liberal) Freedom Party from 1984 to 1986 - the coefficient of the corresponding dummy variable SPDOM becomes significant at the $10 \%$ level (Est. (9)). Thus there is some (weak) evidence that governments dominated by Social Democrats have led to higher federal government debt growth in the past. As this period is also the one in which the People's Party was not in power, the result can also be interpreted in the opposite way, namely that there is some empirical evidence for a higher primary surplus (smaller budget deficit) in periods with the Conservative party in government.

Summing up, there is some empirical indication that the participation of the Social Democrats in government tends to increase the primary deficit. However, the influence of such participation is much smaller than the change of the paradigm of budgetary policy regarding significant reactions to the unemployment rate. If we include a specification with a coefficient of $U R$ only for the second period (1975-2003), all dummy variables for the participation of specific political parties in government become completely insignificant. This result indicates that - contrary to frequent presumptions in the Austrian political debate - the development of 
the federal government debt in Austria is not primarily influenced by the participation of the Social Democrats in government (i.e. that fiscal policy is driven by ideology), but that structural causes and the paradigm shift in budgetary policy are the main driving forces. This seems plausible particularly because, from 1987 to 1999, the People's Party was in a coalition government with the Social Democrats so that either party could have blocked a purely ideology-driven fiscal policy. Moreover, since 2000, a right-wing coalition has been in power. Yet there is still no strong empirical evidence that this has led to a paradigm change in fiscal policy.

\subsection{Influence of Coalitions and the Form of Government}

Having identified a weak influence of political ideology, we next turn to the form of government. According to some public-choice theories, one would expect that a coalition government might increase public debt and reduce the primary surplus. The estimation results for Austria show the opposite to be true. During the periods 1960 to 1966 and 1984 to 2003, governments formed by coalitions of two parties were responsible for fiscal policies. Except for the period of 1984 to 1986 and since 2000, the Social Democrats and the Austrian People's Party formed the Austrian government. First, we test the influence of this so-called "Grand Coalition" by introducing a dummy variable GC. Est. (10) in Table 5 shows the results. The "Grand Coalition" did not lead to significantly higher budget deficits in this period. Instead, forming a coalition generally seems to affect the primary surplus in Austria in a positive direction, as is shown by introducing a coalition dummy COAL (Est. (11)). The effect is not only significant at the $5 \%$ level of significance, but also of remarkable size. 
Table 5: Influence of the Form of Government on Budgetary Policies in Austria (dependent variable: primary surplus of the federal government budget, ratio to GDP)

\begin{tabular}{|c|c|c|c|}
\hline & Est. (10) & Est. (11) & Est. (12) \\
\hline & $\begin{array}{l}\text { Coefficient } \\
\text { (t-statistic) }\end{array}$ & $\begin{array}{l}\text { Coefficient } \\
\text { (t-statistic) }\end{array}$ & $\begin{array}{l}\text { Coefficient } \\
\text { (t-statistic) }\end{array}$ \\
\hline \multirow[t]{2}{*}{ Constant } & -3.8827 & -3.4983 & \\
\hline & $(-8.7437 * *)$ & $(-7.2320 * *)$ & \\
\hline \multirow[t]{2}{*}{$d_{t-1}$} & 0.4379 & 0.3824 & 0.3712 \\
\hline & $\left(9.4751^{* *}\right)$ & $\left(7.7785^{* *}\right)$ & $\left(8.1285^{* *}\right)$ \\
\hline \multirow[t]{2}{*}{$d_{t-1} \cdot D 75$} & -0.2712 & -0.2329 & -0.2300 \\
\hline & $(-7.6873 * *)$ & $(-6.2208 * *)$ & $\left(-6.8106^{* *}\right)$ \\
\hline \multirow[t]{2}{*}{$U R$} & -0.7776 & -0.8006 & -0.8018 \\
\hline & $(-3.5624 * *)$ & $(-4.1712 * *)$ & $(-4.0011 * *)$ \\
\hline$G C(=1$ for period & 0.2058 & & -2.4321 \\
\hline 1960-1966, 1987-1999) & $(0.6740)$ & & $(-3.5939 * *)$ \\
\hline COAL $(=1$ for period & & 0.8106 & \\
\hline 1960-1966, 1984-1999) & & $(2.2781 *)$ & \\
\hline$S C(=1$ for period & & & -3.0846 \\
\hline 1984-1986) & & & $(-5.1154 * *)$ \\
\hline SPA $(=1$ for period & & & -3.3322 \\
\hline 1971-1983) & & & $(-9.0727 * *)$ \\
\hline$V P A(=1$ for period & & & -3.1018 \\
\hline 1967-1970) & & & $(-4.9253 * *)$ \\
\hline$V K K(=1$ for period & & & -1.4059 \\
\hline 2000-2003) & & & $(-1.7941(*))$ \\
\hline \multirow[t]{2}{*}{$A R(1)$} & 0.7615 & 0.8876 & 0.6764 \\
\hline & $\left(4.7818^{* *}\right)$ & $\left(5.5714^{* *}\right)$ & $\left(4.3606^{* *}\right)$ \\
\hline \multirow[t]{2}{*}{$A R(2)$} & -0.4005 & -0.4214 & -0.5344 \\
\hline & $\left(-2.4528^{*}\right)$ & $\left(-2.5983^{*}\right)$ & $(-3.5131 * *)$ \\
\hline $\bar{R}^{2}$ & 0.8813 & 0.8935 & 0.9085 \\
\hline F-statistic & 51.7147 & 58.3092 & \\
\hline Durbin-Watson & 1.8886 & 1.8665 & 1.9696 \\
\hline No. of observations & 42 & 42 & 42 \\
\hline
\end{tabular}

OLS estimation; ** $\mathrm{p}<0.01, * \mathrm{p}<0.05,(*) \mathrm{p}<0.1$

For the last model, we split the constant of the regression equation into the periods when the Social Democrats or the Austrian People's Party had sole responsibility ( $S P A$ and $V P A$, respectively) and when Austria was governed by the "Small Coalition" (SP - FP), the "Grand 
Coalition" (SP - VP or VP - SP), and the "Reform Coalition" (2000 to 2003, a coalition of the Austrian People's Party and the Austrian Freedom Party). Est. (12) shows the results. In periods when the Social Democrats had sole responsibility, the coefficient (the primary surplus-to-GDP ratio, apart from the structural break, the mean reversion and the unemployment influences) is smaller than the respective coefficient for other periods. The largest coefficient occurs in the period of the "Reform Coalition", followed by the "Grand Coalition". Wald coefficient tests (Table 6) show that the coefficients of SPA, SC ("Small Coalition") and VPA are not significantly different from each other. On the other hand, the coefficients for $V K K$ ("Reform Coalition") and $G C$ ("Grand Coalition") are significantly different from all other coefficients. These results corroborate the findings discussed above.

Table 6: Significance of the Differences in Budgetary Policies for Alternative Forms of Government (Wald tests)

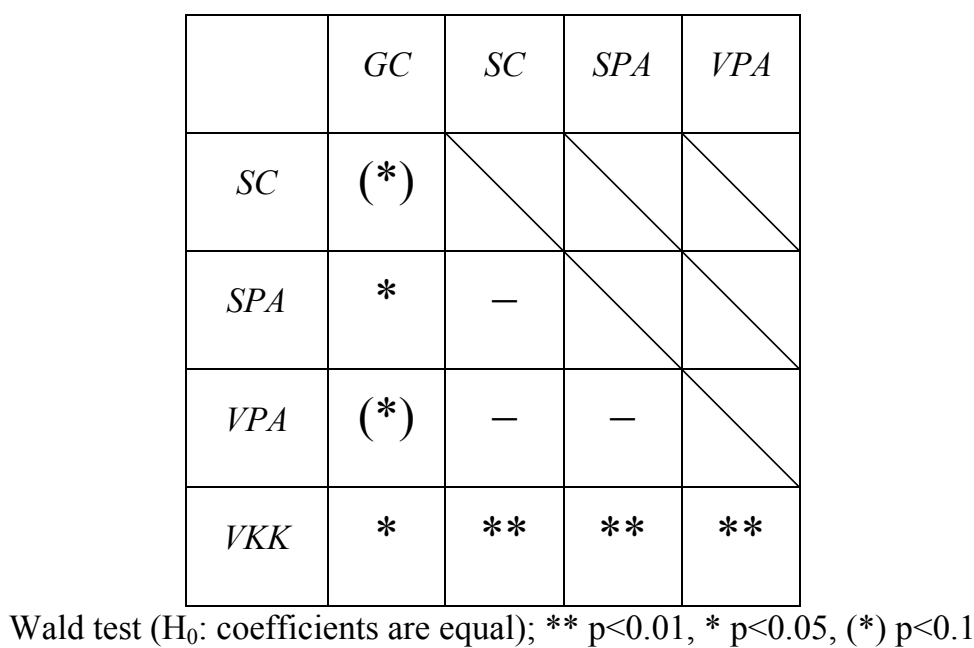

In conclusion, this section presents some empirical evidence that governments in Austria dominated solely by one party run deficits that are higher than those formed by coalitions of the two large parties or the two conservative parties in Austria. Coalition governments apparently find it easier to consolidate the budget and to deal with the resulting losses in popoularity. Alternatively, two parties in government control each other while parliamentary control by opposition parties in the case of only one party in office is not as effective at 
stabilizing the federal budget. However, these results have to be interpreted with caution, as the estimations are not robust regarding changes of specifications. If, for example, the rate of unemployment is included only for the second period, the dummy variables denoting coalitions $(G C, C O A L)$ become insignificant and there is no significant difference between different forms of governments.

\subsection{Political Cycles in Austria}

Finally, we test some hypotheses on the political business cycle. According to this theory, we would expect smaller primary surpluses in election years (dummy variable ELECT). Moreover, primary surpluses might be increasingly higher the more time there is until the next election (variable DIST; in years).

Table 7 shows the results of these estimations. We first test the hypothesis of lower primary surpluses in election years. Est. (13) presents the coefficients; those of the variables included previously are approximately of the same order of magnitude as in the models estimated before. The coefficient for the election year (ELECT) has the expected negative sign but is not significantly different from zero. This result is robust with respect to changes in the specification, e.g. taking into account reactions to the rate of unemployment only in the second sub-period. If the model is estimated only for the first or the second sub-period, the coefficient of ELECT is insignificant too.

We next test the influence of the distance to the next election (Est. (14), variable DIST). Again, the estimation does not yield a significant coefficient, neither for the whole period nor for the sub-periods. 
Table 7: Political Business Cycles in Austrian Budgetary Policies (dependent variable: primary surplus of the federal government budget, ratio to GDP)

\begin{tabular}{|c|c|c|}
\hline & $\begin{array}{c}\text { Est. (13) } \\
\text { Coefficient } \\
\text { (t-statistic) }\end{array}$ & $\begin{array}{c}\text { Est. (14) } \\
\text { Coefficient } \\
\text { (t-statistic) }\end{array}$ \\
\hline \multirow[t]{2}{*}{ Constant } & -3.9873 & -4.0162 \\
\hline & $(-9.7793 * *)$ & $(-9.9193 * *)$ \\
\hline \multirow[t]{2}{*}{$d_{t-1}$} & 0.4438 & 0.4462 \\
\hline & $(9.6057 * *)$ & $\left(9.7776^{* *}\right)$ \\
\hline \multirow[t]{2}{*}{$d_{t-1} \cdot D 75$} & -0.2805 & -0.2819 \\
\hline & $(-8.5575 * *)$ & $(-8.7068 * *)$ \\
\hline \multirow[t]{2}{*}{$U R$} & -0.7094 & -0.7160 \\
\hline & $\left(-3.8156^{* *}\right)$ & $(-3.8974 * *)$ \\
\hline ELECT $(=1$ in & -0.0325 & \\
\hline election years) & $(-0.2481)$ & \\
\hline DIST (distance to next & & 0.0071 \\
\hline election, in years) & & $(0.1204)$ \\
\hline \multirow[t]{2}{*}{$A R(1)$} & 0.7196 & 0.7157 \\
\hline & $\left(4.6803^{* *}\right)$ & $(4.6673 * *)$ \\
\hline \multirow[t]{2}{*}{$A R(2)$} & -0.3865 & -0.3886 \\
\hline & $(-2.4097 *)$ & $(-2.4312 *)$ \\
\hline $\bar{R}^{2}$ & 0.8799 & 0.8798 \\
\hline F-statistic & 51.0863 & 51.0127 \\
\hline Durbin-Watson & 1.9223 & 1.9161 \\
\hline No. of observations & 42 & 42 \\
\hline Period & $1962-2003$ & $1962-2003$ \\
\hline
\end{tabular}

Therefore we conclude that there are no indications of a political business cycle in Austria in the period 1960 to 2003 .

\subsection{Effects of the Maastricht Treaty}

Next, we investigate whether the fiscal convergence criteria of the Maastricht treaty had any effect on the Austrian primary surplus. A dummy is introduced which takes the value of 1 for the years from 1997 on. It seems plausible that the framework of the Third Stage of the 
European Economic and Monetary Union might have put some pressure on national governments to reduce public debt and consequently also to increase the primary surplus.

Table 8: Effects of the Maastricht Treaty (dependent variable: primary surplus of the federal government budget, ratio to GDP)

\begin{tabular}{|c|c|c|}
\hline & Est. (15) & Est. (16) \\
\hline & $\begin{array}{l}\text { Coefficient } \\
\text { (t-statistic) }\end{array}$ & $\begin{array}{l}\text { Coefficient } \\
\text { (t-statistic) }\end{array}$ \\
\hline Constant & $\begin{array}{r}-3.7346 \\
\left(-10.9610^{* *}\right)\end{array}$ & \\
\hline$d_{t-1}$ & $\begin{array}{r}0.4112 \\
(9.2660 * *)\end{array}$ & $\begin{array}{r}0.3497 \\
(7.5448 * *)\end{array}$ \\
\hline$d_{t-1} \cdot D 75$ & $\begin{array}{r}-0.2707 \\
\left(-9.8554^{* *}\right)\end{array}$ & $\begin{array}{r}-0.2192 \\
(-6.5017 * *)\end{array}$ \\
\hline$U R$ & $\begin{array}{r}-0.6216 \\
\left(-3.6077^{* *}\right)\end{array}$ & $\begin{array}{r}-0.7791 \\
(-3.9343 * *)\end{array}$ \\
\hline MAASTRICHT & $\begin{array}{r}0.9495 \\
\left(2.5880^{*}\right)\end{array}$ & $\begin{array}{r}0.7000 \\
\left(1.8422\left(^{*}\right)\right)\end{array}$ \\
\hline$G C(=1$ for period & & -2.2079 \\
\hline 1960-1966, 1987-1999) & & $(-3.2466 * *)$ \\
\hline$S C(=1$ for period & & -2.8164 \\
\hline 1984-1986) & & $\left(-4.6105^{* *}\right)$ \\
\hline$S P A(=1$ for period & & -3.1432 \\
\hline 1971-1983) & & $\left(-8.4041^{* *}\right)$ \\
\hline$V P A(=1$ for period & & -2.8933 \\
\hline 1967-1970) & & $(-4.5343 * *)$ \\
\hline$V K K(=1$ for period & & -1.5779 \\
\hline 2000-2003) & & $\left(-2.0868^{*}\right)$ \\
\hline$A R(1)$ & 0.5714 & 0.6169 \\
\hline & $(3.6653 * *)$ & $(3.7961 * *)$ \\
\hline$A R(2)$ & -0.3910 & -0.5059 \\
\hline & $\left(-2.4531^{*}\right)$ & $(-3.1142 * *)$ \\
\hline $\bar{R}^{2}$ & 0.8980 & 0.9152 \\
\hline F-statistic & 61.1656 & - \\
\hline Durbin-Watson & 2.0026 & 2.0089 \\
\hline No. of observations & 42 & 42 \\
\hline
\end{tabular}


The results of the esimations are presented in Table 8. Est. (15) adds the Maastricht dummy to the basic estimation used in the previous sections. The Maastricht dummy is significant (although only at the 95 percent level) and shows that the primary surplus was 0.95 perentage points higher in the period under consideration. If the dummy is added to the equation used to estimate the influence of political parties (Est. (12)), it still remains significant (at the 90 percent level) with a slightly lower magnitude of 0.7 percent.

We conclude that the Maastricht treaty had some positive effect on the primary surplus in Austria.

\section{Summary and Conclusions}

The following conclusions can be drawn from the econometric estimations:

1. The Bohn model of sustainability of public debt in Austria is clearly supported by the data: The Austrian primary fiscal surplus of the central government reacts to high public debt to counteract the debt increase. However, this tendency was clearly weaker after the first oil price shock in the 1970s than before. A structural break can thus be identified between the years 1974 and 1975 .

2. There is some empirical indication that the participation of the Social Democrats in government increases the primary deficit. Yet the influence of this participation is much smaller than the change in the paradigm of budgetary policy regarding significant reactions to the rate of unemployment. The development of public debt in Austria seems to be driven not primarily by partisan ideology; instead structural causes and the change in the budgetary policy paradigm (partly due to the ideas of "Austrokeynesianism") are the main driving forces. 
3. We find some empirical evidence that governments in Austria dominated by one party run deficits that are higher than those produced by governments formed by coalitions of the two large parties or the two right-wing parties. However, these results have to be interpreted with caution as the estimations are not robust with respect to different specifications.

4. There are no indications of a political business cycle in Austria in the period 1960 to 2003, which is in line with most previous empirical work for Austria.

5. The Maastricht process has contributed to the reduction of public debt growth in Austria.

It remains to be seen whether the deceleration of public debt growth, which came about with Austria's entry into the EU and the corresponding requirement of consolidating the public budget, will retain momentum and bring public debt down below the 60 percent of GDP level regarded as critical by the Maastricht treaty and the SGP. In any case, it is highly unlikely that levels of 10 to 15 percent, which prevailed before the first oil price shock, can be obtained in the foreseeable future. In that sense, the 1970s in fact brought about a fundamental change in the political and economic framework of many industrial countries, including Austria. 


\section{References}

Alesina, A. and Perotti, R. (1995) 'The Political Economy of Budget Deficits', IMF Staff Papers 42(1), pp. 1-31.

Barro, R. J. (1979) 'On the Determination of the Public Debt', Journal of Political Economy 87(5), pp. 940-971.

Bohn, H. (1998) 'The Behavior of U.S. Public Debt and Deficits'. Quarterly Journal of Economics 113(3), pp. 949-963.

Bohn, H. (2006), 'The Sustainability of Fiscal Policy in the United States', to appear.

Neck, R., and M. Getzner (2001) 'Politico-Economic Determinants of Public Debt Growth: A Case Study for Austria', Public Choice 109, pp. 243-268.

Neck, R., and G. Haber (2006) 'The Long Shadow of "Austrokeynesianism"? Public Debt Sustainability in Austria', to appear.

Roubini, N. and Sachs, J.D. (1989), 'Political and Economic Determinants of Budget Deficits in the Industrial Democracies', European Economic Review 33(6), pp. 903-938. 


\section{CESifo Working Paper Series}

(for full list see www.cesifo-group.de)

1752 Helge Berger and Michael Neugart, Labor Courts, Nomination Bias, and Unemployment in Germany, June 2006

1753 Chris van Klaveren, Bernard van Praag and Henriette Maassen van den Brink, A Collective Household Model of Time Allocation - a Comparison of Native Dutch and Immigrant Households in the Netherlands, June 2006

1754 Marko Koethenbuerger, Ex-Post Redistribution in a Federation: Implications for Corrective Policy, July 2006

1755 Axel Dreher, Jan-Egbert Sturm and Heinrich Ursprung, The Impact of Globalization on the Composition of Government Expenditures: Evidence from Panel Data, July 2006

1756 Richard Schmidtke, Private Provision of a Complementary Public Good, July 2006

1757 J. Atsu Amegashie, Intentions and Social Interactions, July 2006

1758 Alessandro Balestrino, Tax Avoidance, Endogenous Social Norms, and the Comparison Income Effect, July 2006

1759 Øystein Thøgersen, Intergenerational Risk Sharing by Means of Pay-as-you-go Programs - an Investigation of Alternative Mechanisms, July 2006

1760 Pascalis Raimondos-Møller and Alan D. Woodland, Steepest Ascent Tariff Reforms, July 2006

1761 Ronald MacDonald and Cezary Wojcik, Catching-up, Inflation Differentials and Credit Booms in a Heterogeneous Monetary Union: Some Implications for EMU and new EU Member States, July 2006

1762 Robert Dur, Status-Seeking in Criminal Subcultures and the Double Dividend of ZeroTolerance, July 2006

1763 Christa Hainz, Business Groups in Emerging Markets - Financial Control and Sequential Investment, July 2006

1764 Didier Laussel and Raymond Riezman, Fixed Transport Costs and International Trade, July 2006

1765 Rafael Lalive, How do Extended Benefits Affect Unemployment Duration? A Regression Discontinuity Approach, July 2006

1766 Eric Hillebrand, Gunther Schnabl and Yasemin Ulu, Japanese Foreign Exchange Intervention and the Yen/Dollar Exchange Rate: A Simultaneous Equations Approach Using Realized Volatility, July 2006 
1767 Carsten Hefeker, EMU Enlargement, Policy Uncertainty and Economic Reforms, July 2006

1768 Giovanni Facchini and Anna Maria Mayda, Individual Attitudes towards Immigrants: Welfare-State Determinants across Countries, July 2006

1769 Maarten Bosker and Harry Garretsen, Geography Rules Too! Economic Development and the Geography of Institutions, July 2006

1770 M. Hashem Pesaran and Allan Timmermann, Testing Dependence among Serially Correlated Multi-category Variables, July 2006

1771 Juergen von Hagen and Haiping Zhang, Financial Liberalization in a Small Open Economy, August 2006

1772 Alessandro Cigno, Is there a Social Security Tax Wedge?, August 2006

1773 Peter Egger, Simon Loretz, Michael Pfaffermayr and Hannes Winner, Corporate Taxation and Multinational Activity, August 2006

1774 Jeremy S.S. Edwards, Wolfgang Eggert and Alfons J. Weichenrieder, The Measurement of Firm Ownership and its Effect on Managerial Pay, August 2006

1775 Scott Alan Carson and Thomas N. Maloney, Living Standards in Black and White: Evidence from the Heights of Ohio Prison Inmates, 1829 - 1913, August 2006

1776 Richard Schmidtke, Two-Sided Markets with Pecuniary and Participation Externalities, August 2006

1777 Ben J. Heijdra and Jenny E. Ligthart, The Transitional Dynamics of Fiscal Policy in Small Open Economies, August 2006

1778 Jay Pil Choi, How Reasonable is the 'Reasonable' Royalty Rate? Damage Rules and Probabilistic Intellectual Property Rights, August 2006

1779 Ludger Woessmann, Efficiency and Equity of European Education and Training Policies, August 2006

1780 Gregory Ponthiere, Growth, Longevity and Public Policy, August 2006

1781 Laszlo Goerke, Corporate and Personal Income Tax Declarations, August 2006

1782 Florian Englmaier, Pablo Guillén, Loreto Llorente, Sander Onderstal and Rupert Sausgruber, The Chopstick Auction: A Study of the Exposure Problem in Multi-Unit Auctions, August 2006

1783 Adam S. Posen and Daniel Popov Gould, Has EMU had any Impact on the Degree of Wage Restraint?, August 2006 
1784 Paolo M. Panteghini, A Simple Explanation for the Unfavorable Tax Treatment of Investment Costs, August 2006

1785 Alan J. Auerbach, Why have Corporate Tax Revenues Declined? Another Look, August 2006

1786 Hideshi Itoh and Hodaka Morita, Formal Contracts, Relational Contracts, and the Holdup Problem, August 2006

1787 Rafael Lalive and Alejandra Cattaneo, Social Interactions and Schooling Decisions, August 2006

1788 George Kapetanios, M. Hashem Pesaran and Takashi Yamagata, Panels with Nonstationary Multifactor Error Structures, August 2006

1789 Torben M. Andersen, Increasing Longevity and Social Security Reforms, August 2006

1790 John Whalley, Recent Regional Agreements: Why so many, why so much Variance in Form, why Coming so fast, and where are they Headed?, August 2006

1791 Sebastian G. Kessing and Kai A. Konrad, Time Consistency and Bureaucratic Budget Competition, August 2006

1792 Bertil Holmlund, Qian Liu and Oskar Nordström Skans, Mind the Gap? Estimating the Effects of Postponing Higher Education, August 2006

1793 Peter Birch Sørensen, Can Capital Income Taxes Survive? And Should They?, August 2006

1794 Michael Kosfeld, Akira Okada and Arno Riedl, Institution Formation in Public Goods Games, September 2006

1795 Marcel Gérard, Reforming the Taxation of Multijurisdictional Enterprises in Europe, a Tentative Appraisal, September 2006

1796 Louis Eeckhoudt, Béatrice Rey and Harris Schlesinger, A Good Sign for Multivariate Risk Taking, September 2006

1797 Dominique M. Gross and Nicolas Schmitt, Why do Low- and High-Skill Workers Migrate? Flow Evidence from France, September 2006

1798 Dan Bernhardt, Stefan Krasa and Mattias Polborn, Political Polarization and the Electoral Effects of Media Bias, September 2006

1799 Pierre Pestieau and Motohiro Sato, Estate Taxation with Both Accidental and Planned Bequests, September 2006

1800 Øystein Foros and Hans Jarle Kind, Do Slotting Allowances Harm Retail Competition?, September 2006 
1801 Tobias Lindhe and Jan Södersten, The Equity Trap, the Cost of Capital and the Firm's Growth Path, September 2006

1802 Wolfgang Buchholz, Richard Cornes and Wolfgang Peters, Existence, Uniqueness and Some Comparative Statics for Ratio- and Lindahl Equilibria: New Wine in Old Bottles, September 2006

1803 Jan Schnellenbach, Lars P. Feld and Christoph Schaltegger, The Impact of Referendums on the Centralisation of Public Goods Provision: A Political Economy Approach, September 2006

1804 David-Jan Jansen and Jakob de Haan, Does ECB Communication Help in Predicting its Interest Rate Decisions?, September 2006

1805 Jerome L. Stein, United States Current Account Deficits: A Stochastic Optimal Control Analysis, September 2006

1806 Friedrich Schneider, Shadow Economies and Corruption all over the World: What do we really Know?, September 2006

1807 Joerg Lingens and Klaus Waelde, Pareto-Improving Unemployment Policies, September 2006

1808 Axel Dreher, Jan-Egbert Sturm and James Raymond Vreeland, Does Membership on the UN Security Council Influence IMF Decisions? Evidence from Panel Data, September 2006

1809 Prabir De, Regional Trade in Northeast Asia: Why do Trade Costs Matter?, September 2006

1810 Antonis Adam and Thomas Moutos, A Politico-Economic Analysis of Minimum Wages and Wage Subsidies, September 2006

1811 Guglielmo Maria Caporale and Christoph Hanck, Cointegration Tests of PPP: Do they also Exhibit Erratic Behaviour?, September 2006

1812 Robert S. Chirinko and Hisham Foad, Noise vs. News in Equity Returns, September 2006

1813 Oliver Huelsewig, Eric Mayer and Timo Wollmershaeuser, Bank Behavior and the Cost Channel of Monetary Transmission, September 2006

1814 Michael S. Michael, Are Migration Policies that Induce Skilled (Unskilled) Migration Beneficial (Harmful) for the Host Country?, September 2006

1815 Eytan Sheshinski, Optimum Commodity Taxation in Pooling Equilibria, October 2006

1816 Gottfried Haber and Reinhard Neck, Sustainability of Austrian Public Debt: A Political Economy Perspective, October 2006 